TTR

Traduction, terminologie, re?daction

\title{
The Politics of Non-Translation: A Case Study in Anglo-Portuguese Relations
}

\section{João Ferreira Duarte}

Volume 13, numéro 1, 1er semestre 2000

Idéologie et traduction

Ideology and Translation

URI : https://id.erudit.org/iderudit/037395ar

DOI : https://doi.org/10.7202/037395ar

Aller au sommaire du numéro

\section{Éditeur(s)}

Association canadienne de traductologie

ISSN

0835-8443 (imprimé)

1708-2188 (numérique)

Découvrir la revue

Citer cet article

Ferreira Duarte, J. (2000). The Politics of Non-Translation: A Case Study in Anglo-Portuguese Relations. TTR, 13(1), 95-112.

https://doi.org/10.7202/037395ar

\section{Résumé de l'article}

Une politique de non-traduction dans le cadre des relations anglo-portugaises — La possibilité de considérer les aspects théoriques et analytiques d'objets catégorisés, d'un point de vue épistémologique, empiriquement absents a été l'une des avenues les plus prometteuses découlant de la nouvelle orientation fonctionnaliste et cibliste de la traductologie. La non-traduction devient donc accessible à la recherche au niveau tant lexical que textuel. Dans ce contexte, le présent article vise deux objectifs : établir des catégories de non-traduction et examiner une situation où l'on évite délibérément de traduire pour des raisons idéologiques. Cette étude de cas porte sur l'histoire de l'accueil fait aux oeuvres de Shakespeare au Portugal alors qu'une période de quinze années intenses de traduction et de popularité sans précédent a fait place à l'absence quasi totale de nouvelles traductions en portugais durant la dernière décennie du XIXe siècle. On remarque que ce cas probant de non-traduction découlait d'une vague nationaliste anti-britannique qui a balayé le pays à la suite du conflit colonial portant sur une partie des territoires de l'Afrique du Sud.
Tous droits réservés (C TTR: traduction, terminologie, rédaction — Les auteurs, 2000
Ce document est protégé par la loi sur le droit d'auteur. L’utilisation des services d'Érudit (y compris la reproduction) est assujettie à sa politique d'utilisation que vous pouvez consulter en ligne.

https://apropos.erudit.org/fr/usagers/politique-dutilisation/ 


\title{
The Politics of Non-Translation: A Case Study in Anglo-Portuguese Relations ${ }^{1}$
}

\author{
João Ferreira Duarte
}

In the recent history of Translation Studies, Gideon Toury's statement in the early 80s that "translations are, in one way or another, facts of the target system" (1982, p. 26) may certainly be taken, together with its implications in theory and the research work that ensued, as signalling the event of a true epistemological break in the discipline. In Louis Althusser's Marxist philosophy, the concept of such a rupture has the function of giving theoretical visibility to the distinction between ideology and science, as well as pinning down the moment where a new problematic is founded by breaking free from pre-scientific knowledge (1966, p. 32; 1970, p. 153). While the opposition ideology/science, with its severe structuralist overtones, is not generally tenable any more, as far as the field of Translation Studies is concerned the concept may help us to account for what Susan Bassnett called "the great leap forward" (199394 , p. 171). In this context, rather than positing the domination of ideology in relation to supposedly ideology-free scientific discourse, the leap - or the break - has made it possible to disclose the ideology of

\footnotetext{
I The author wishes to thank his colleagues Isabel Lousada (New University of Lisbon) for kindly providing him with data from her research work on the establishment of a British bibliography in Portugal, and Maria Helena Serôdio (University of Lisbon), who made available to him information from the archive of our late colleague Osório Mateus. Thanks are also due to Instituto Camões and FCT (Programa Lusitânia) for financial assistance.
} 
domination at work in the study of translation. The hallowed privilege of the original, the marginalisation of the translator in the market of discursive and economic exchanges, and the prescriptive and normative bias that used to rule most of the contrastive studies were characteristic features of the field that the systemic or culturalist break referred to has allowed us to be aware of, criticise, and displace, as has been abundantly commented upon. Thus the paternalist and colonialist nature of some key metaphors long employed in describing the relation between target and source texts - "fidelity" being perhaps the most conspicuous of all - has been amply demonstarted by Lori Chamberlain among others (see Chamberlain, 1988; Simon, 1996, pp. 10-14).

More importantly for the purposes of this paper, targetorientedness as epistemological break also made it possible to uncover new objects of knowledge, or rather to construct objects that simply were not available as long as it was assumed that the co-presence of two comparable texts (languages) was the Alpha and Omega of the study of translation. Pseudotranslation is just one of them, and so is - I would claim - non-translation, in its different guises both textual and cultural. Before presenting and discussing a particularly enlightening case of nontranslation, it seems pertinent to dwell in some detail on the various manifestations of the concept in order to get a fairly clear picture of what we are dealing with here.

I will thus propose the following typology of non-translation categories, illustrated with brief examples that are meant to be treated not as mere localist anecdotes but rather as springboards to further research into the referential validation of the theory.

1. Omission. A certain item in the source text fails to be replaced by a corresponding item in the target text, regardless of whether or not it is to be compensated for elsewhere. This is what Toury calls "zero replacement", the legitimacy of which as a translation solution was often neglected due to the prescriptive attitude once common among scholars $(1995$, p. 82).

2. Repetition, A lexical or syntactic item in the source text is carried over unchanged into the target text. This is the well-known case of borrowings or loanwords, which are sometimes used to add local 
colour or exotic atmosphere to a translation but often reflect the uneven relations between cultures. In fact, it is not hard to trace the flow at various points in history of non-translated transfers from central, prestigious languages into peripheral languages owing to cultural, economic or political ascendancy. One example among many is provided by Meta Grosman, who in discussing the Slovene translation of Jane Austen's Pride and Prejudice notices that the original words "gentleman" and "gentlemanlike" are sometimes replaced by a rough equivalent, sometimes left untranslated. That "the use of this loan-word is permissible according to Slovene dictionaries," (1994, p. 54) as she informs us, goes a long way, I think, to illustrate the power relations that govern languages and cultures and, furthermore, to make us suspicious of any theory that too readily sets up tight boundaries between verbal and non-verbal phenomena.

3. Language closeness. Moving now towards higher-order units of translation, a situation may be found where the structural proximity of two languages works, at least in part, as an otherwise unexpected obstacle to translation. In 1978 a prominent Portuguese writer, critic, and translator maintained that "literatures in Spanish are in principle readable by those of us who are not schooled in foreign languages; that is the reason why they have been less translated here" (Sena, 1978, p. 15, my translation). While conceding that other factors may also account for this case of nontranslation and moreover taking into consideration that the situation has recently been reversed, it is beyond doubt that language closeness played a major role in explaining the empirically observable scarcity of translations from Spanish and Latin-American literatures into Portuguese before the $80 \mathrm{~s}$ as compared to other European languages. And this still holds true even when such a vague sociological notion as the average reader is being implicitly used.

4. Bilingualism. Texts originating from a particular source culture or cultures may not be translated because the reading public (or its dominant fraction) are able to read them in the language in which they were written and thus no demand for local translations is generated. José Lambert mentions the case of Belgium, where "there are hardly any translations of French works into Dutch, except between 1830 and 1850 , for these books were (and still are) read in the original French by all (most) Belgian intellectuals." (1995, p. 105). It goes without saying that 
the bilingual skills of this specific community, as José Lambert does not fail to make clear, are the product of French cultural domination over the whole of Belgium.

5. Cultural distance. I am employing this phrase to describe the fact that a highly canonical text or series of texts fail over a more or less lengthy period of time to be admitted into some target system for no other reason than cultural remoteness, which may stem from hostility or indifference and may lead to a dearth of experts able to tackle the translation. It comes to mind that the first translation of the Qur'an published in Portugal dates from as recently as 1978. Historical and religious constraints help us explain why for centuries there was no community in the country capable of fostering demand for a translation of the sacred book of Islam. It was only in the wake of the independence of the former Portuguese African colonies in 1975 that an organised Islamic community sprang up which was sizeable enough to warrant readership for two different translations of the Qur'an and two editions of these within a period of ten years.

6. Institutionalised censorship. There is no shortage of historical evidence that points to the fact that non-translation is one of the many cultural consequences of the political institution of censorship, which, as we all know, is set up to prevent circulation of material that is felt to threaten official ideology. During the 48 years of the Fascist regime in Portugal, translations of Marx and Engels' works were of course strictly outlawed. Curiously enough, some of Lenin's works, namely those like Materialism and Empiriocriticism that did not carry overtly political titles, were tolerated on condition, however, that the author's name was printed as Vladimir Ilitch Ulianov.

7. Ideological embargo. I tentatively propose this category label to describe non-translation that results from the clash of a community's system of values and some shattering political event. Unlike category (5), the cultural objects subject to embargo had been previously familiar to the recipient system; unlike category (6), what is at stake here is not a Stateenforced ban but rather the "spontaneous" action of civil society or sections of it. In the remainder of my paper, I will focus on a blatant case of ideological embargo, one that concerns Shakespeare reception in Portugal in the last quarter of the $19^{\text {th }}$ century. 
The first recorded reference to Shakespeare in Portugal dates from 1761. Writing in the first literary journal ever published in the country, its author clearly shows awareness of the canonical status of the poet in the home culture. As might be expected, though, the task of canonising Shakespeare in the target culture, establishing his reputation as the "sublime genius" and "inimitable bard" that would last all through the century and of course beyond fell to the Romantics early in the next century. Most decisive in introducing Shakespeare's plays to a wider public, however, were two prominent features of the Portuguese cultural scene at the time: Italian opera and visiting theatre companies from abroad.

In the second half of the $18^{\text {th }}$ century opera had become the favourite cultural product of the ruling fraction, that is, the aristocracy and the titled bourgeoisie, as well as of foreign residents such as diplomats (Santos, 1983, p. 62). Since its opening in 1793, the Lisbon Opera House (Teatro S. Carlos) regularly and successfully staged the well-known operatic adaptations of Shakespeare's plays: Rossini's Otello, Vaccai's Giulietta e Romeo, Bellini's I Capuletti ed i Montecchi, Verdi's Macbetto, Ambroise Thomas' Hamlet, Gounod's Roméo et Juliette, Verdi's Otello, and Verdi's Falstaff. Thus, in this mediated, intersemiotic manner the owners of a highly ostentatious cultural capital first put Shakespeare on the agenda in Portugal, which, incidentally, helps to explain why translations of libretti were a standard feature of Shakespeare reception in the $19^{\text {th }}$ century.

Foreign theatre companies had also periodically visited the country since the $17^{\text {th }}$ century, initially coming from Spain and later also from Italy and France. Catering to a wider public of theatre-goers, these found an audience for whom the stage was becoming the main source of both aesthetic and political innovation, playing a significant role in the establishment of bourgeois liberties early in the $19^{\text {th }}$ century (Santos 1985, pp. 204-5). Worth mentioning as cultural milestones were the company of Emile Doux with a production of Hamlet in the 1830s and the visits of the Italian actors Ernesto Rossi and Tommaso Salvini in the late 1860s who played the leading roles in Othello, Hamlet, Romeo and Juliet, and Macbeth. Rossi came again later in the century, together with Novelli and 
Emmanuel, and the famous French actress Sarah Bernhardt, who played her travestied Hamlet in Lisbon in 1899. In short,

[...] from the middle of the century onwards, practically every year a foreign company performed in Lisbon, and the great figures of the French, Italian, and Spanish stages got used to including Portugal in their artistic tours. (Rebelo, 1978, p. 185, my translation)

Translations of Shakespeare's plays themselves were, on the whole, slow to catch up with this process of theatrical acculturation. Before the last quarter of the $19^{\text {th }}$ century, most of them were made available through the intermediary language of the dominant cultural model: the French versions of Jean-François Ducis, Alfred de Vigny or Victor Hugo, as was the case of the first known play to be translated into Portuguese Othello - late in the $18^{\text {th }}$ century (see Afonso 1993), which was left unpublished and its manuscript only discovered in our century. Literary history records also published fragments of As You Like It, Macbeth, and Romeo and Juliet, two other versions of Othello in 1842 and 1856, and Midsummer Night's Dream translated by a leading intellectual of the time in 1874 , not to mention opera libretti and translations reported lost.

As far as translated transfers from the British to the Portuguese systems are concerned, the first half of the $19^{\text {th }}$ century can be seen as the age of Byron and Walter Scott, thus disclosing the imprint of Romantic norms on the literary scene; the "age of Shakespeare" was still to come. In 1877 a young critic writing in English in a Lisbon newspaper complained that "the works of even the most celebrated of English writers are, as it were, a sealed book to the majority of the reading classes in this country." (Pestana, 1930, p. 249) She was referring explicitly to Shakespeare in the context of her review of the reigning King's translation of Hamlet, which had just come out and is generally acknowledged to mark a significant shift in Shakespeare's reception in Portugal. Also, King Luis' other translations, of The Merchant of Venice published in 1879, Richard III published in 1880, and Othello published in 1885, can be said to finally put Shakespeare firmly on the map of the Portuguese reading public. Now, if one looks for reasons why this happened, one will surely not find them in the target texts and their supposed fidelity, although they were translated from the English originals and were not self-styled "imitations" or "adaptations" like so many before. Their importance lies 
rather with the translator himself, whose royal status sufficed to turn a translation fact into a political fact, at a time when political discourse was moving to centre stage and the legitimacy of the monarchic institution was increasingly and openly questioned.

Be that as it may, Shakespeare's dramas and dramatic characters became widely popular: within the next ten years other translations followed the King's Hamlet and two National Theatre productions of Othello and Hamlet, respectively in 1882 and 1887, were highly acclaimed by public and critics alike and have been described as landmarks of Portuguese theatre (see Flor, 1985). Finally it is worth mentioning in this respect the intertextual play of citations, allusions, and even parodies abundantly documented both in literature and the press (Estorninho, 1964, p. 118; Jorge, 1941, pp. 20-21). As a famous contemporary novelist ironically put it,

The Moor's jealousy has fared like ballast in our literary navigation. Desdemona is familiar to every tear-dropping poet. Honest lago is the label to be stuck on the back of every disguised sycophant. Among us even those shoemakers who rip open their unfaithful wives' bellies with their trade knives have the satisfaction of seeing themselves called Othellos on the learned news. (Branco, 1906, p. 33, my translation)

The table in Appendix 1 listing all Shakespeare translations published in Portugal from 1874 to 1900 makes it apparent that they tend to cluster roughly in the ten years that follow 1879 , basically what I called "the age of Shakespeare". However, and more to the point, it shows something else as well, namely a striking blank space of no translations that stretches almost unbroken from 1890 to the turn of the century. Apart from the libretto of Verdi's Falstaff, a few Sonnets and two plays again focusing on the figure of Falstaff published in 1899, no new translations or new editions came out and certainly none of those plays that had been most authoritative in the previous decade.

It seems, thus, that we have met with a clear-cut instance of nontranslation, the causes of which need to be investigated. The hypothesis I am going to advance now points to what I have called "ideological embargo". In other words, in order to be able to account for this prima facie unexpected lack of Shakespeare translations, we must temporarily leave the literary system and look at the broader arena of the social 
formation, in particular at the political events that took place in 1890 and rocked Portuguese society to its foundations with long-lasting effects. I am referring to what both contemporary press and current historiography came to identify as the British Ultimatum.

The circumstances leading to and following up this historical event are well documented (see, among others, Hammond 1966; Axelson, 1967; Nowell, 1982; Clarence-Smith, 1985; Homem, 1985; Teixeira, 1985; Coelho, 1996), so that I will restrict myself to a brief summary here. From the larger point of view of international relations, the Ultimatum was a minor incident in the so-called "scramble for Africa", which describes the wholesale exploration and colonisation of the African continent and its partition among some of the European powers, a process that began to take shape in the $1880 \mathrm{~s}$. While Britain, France, Germany, Belgium and Portugal jostled each other in Southern and Central Africa in a bid to secure spheres of influence, protectorates, trade routes, and tariff benefits, the region was being invaded by a steady stream of explorers, missionaries, capitalists, adventurers of all sorts, and the inevitable expeditionary forces. As conflicts were bound to spring up, the Berlin Conference of 1884-85 attempted to come up with a diplomatic framework for settling them, namely by establishing international arbitration in case of dispute and by ruling that effective occupation of territory rather than discovery was the necessary condition to claim right of possession.

At about this time, it became Portuguese official policy to claim sovereignty over a large corridor linking the coastal areas of Angola and Mozambique long in possession of Portugal, across a vast hinterland still largely unexplored let alone occupied, encompassing territory that would later become part of Nyasaland and the Rhodesias and the cause of the future Anglo-Portuguese controversy. Such a claim was soon to be cartographically materialised in the famous colour-coded maps appended by the Portuguese delegation to the 1886 treaties signed with France and Germany. On the maps the rose-coloured area stood for Portuguese territory, and although it represented more wishful thinking than full ownership, as one historian puts it (Nowell, 1982, p. 136), the maps quickly took hold of the people's imagination and became a kind of national icon embodying the patriotic myth based on the revival of lost imperial grandeur. If, as Susan Bassnett contends (1993, p. 43), the map- 
maker, like the translator and the travel writer, is engaged in a process of manipulation rather than of objective and faithful representation, then these maps certainly offer powerful evidence of an ideologically motivated re-organisation of geographical space.

As was only to be expected, the policy thus mapped out was soon to bring Portugal into headlong conflict with British interests in the area, in particular with Cecil Rhodes' ambition of pushing northwards to establish the famous Cape-to-Cairo link. To cut a long story short, the mounting tension between the two colonial powers throughout 1889 was finally resolved when on January $11^{\text {th }}, 1890$, the British Prime Minister Lord Salisbury formally demanded Portuguese withdrawal from the region on pain of breaking off diplomatic relations and, of course, implying recourse to military action. Given the greatly inferior position of Portugal vis-à-vis the world's superpower of the time, the government had no reasonable alternative but to comply with this ultimatum, which it promptly did but at the cost of unleashing a wave of anti-British nationalism across the country which had far-reaching consequences.

Like everywhere else in Europe, in the 1880s nationalism had become a powerful force in Portugal, no longer the doctrinal core of a few liberal intellectuals who had fought against absolutism earlier in the century, but rather the full-blown ideological cement of a whole "imagined community", to use Benedict Anderson's concept (1991). Predictably enough, following several decades of relative political stability and the slow but steady modernisation of the country's economic structure, the growth of a national consciousness had kept abreast with the rise of an industrial and commercial bourgeoisie and an urban proletariat. Furthermore, it was ultimately fostered by what Benedict Anderson calls print-capitalism, in the powerful shape of the first mass-communications medium - the press - and its ability to construct the new phenomenon of public opinion. At the time of the British Ultimatum, nationalism had become the dominant discourse, grounded on a utopian conception of the awakening of the motherland as an imperial nation eager to redress past humiliations and regain long-lost prestige, equipped with past symbols and present heroes, championed by influential institutions such as the Lisbon Geographical Society and above all the Republican Party, which the political events would soon boost into the forefront of protest and agitation. 
When news of the Ultimatum became public on the day after, it is hard "to exaggerate the intense humiliation felt by all classes" and the "outburst of popular feeling" it provoked (Clarence-Smith, 1985, p. 83). The response was immediate, nation-wide, cut across all sorts of social divisions, and took the form of virulent anti-dynastic and anti-British attitudes. In passionate meetings, street demonstrations, political rallies, in countless poems, articles, pamphlets, even cartoons, Britain was depicted as a treacherous nation of pirates and profit-mongers able to commit the most outrageous and infamous action against her oldest ally. The King, as well as the whole dynasty, on the other hand, were branded as cowards, corrupts, trading the sacredness of the motherland for power and luxury. In fact, as a participant in the events would later put it, there was as a potentially revolutionary situation; but for lack of leadership, the monarchy might very well have collapsed (Teles, 1968, pp. 96-104).

In these circumstances the "popular movement", as the Republican newspapers called it, however broad and vibrant, remained by and large politically innocuous. It assumed such disparate forms as calls to armed resistance, opening a national subscription to buy a warship, harassment of British nationals, boycotting British imports and the sale of British products, refusing admission of British nationals into theatres and hotels, even proposals to purge Portuguese language of English borrowings and ban the teaching of English from Portuguese schools. In short, everything that sounded English was hunted down and publicly stigmatised, therefore it comes as no surprise that a performance of Hamlet then showing at the National Theatre should have been cancelled by the authorities in order to prevent riots (Sequeira, 1955, p. 385).

From our vantage point in the present it is perhaps easy to find this kind of reaction disproportionate or even downright ludicrous. For contemporaries, however, the Ultimatum represented a deep blow to national identity, one, moreover, that was going to be felt for a very long time, henceforward coupling Britain with any threat to the integrity of the colonies and helping to explain why, at the time of the Anglo-Boer war, Portuguese public opinion was firmly on the side of the Boers (Telo, 1991, p. 159). Indeed, writing in 1966, the historian Richard J. Hammond was able to notice that "in Portugal [...] the ultimatum is still a live issue - as is shown by the fact that all documents about it known to exist 
in Lisbon have yet to be thrown open for scholarly inspection" (1966, p. 128). Further, it is possible to trace a direct historical line leading from the events of 1890 to the King's assassination in 1908 and the overthrow of the monarchy in 1910 .

Thus, in the light of the political conjuncture I have just sketched out it is no wonder that translated Shakespeare, like so much else of British origin, was subject to strict ideological embargo, swept away in the nationalist storm until anti-British feelings faded out from the surface of collective life. No other motive can, in fact, plausibly account for the radical case of non-translation of Shakespeare observable from 1890 to 1899. It is all the more remarkable if we look at it against the backdrop of the significant rise in translations of Shakespeare from 1900 onwards, soon to be serialised by a project of publication of the complete works beginning with King Lear in 1905 (Afonso, 1970, p. 71).

Let me point out, however, that an attentive observer of Portuguese cultural life at the turn of the decade might easily make an issue out of my argument on the basis of the repertoire of opera productions staged at the time and all through the 1890s by the Lisbon Opera House. In fact, operatic adaptations of Shakespeare's plays, already popular among opera-goers in the previous decade, became immensely successful in the post-Ultimatum era, in seemingly contradistinction to the fate of published translations. Thus, while the latter were undergoing a process of ideological embargo, as I have attempted to show, operatic Shakespeare was well and thriving: Verdi's Ottelo and Falstaff were regularly produced season after season, and occasionally, Thomas's Hamlet and Bellini's I Capuletti; indeed, Ottelo can be considered, by contemporary standards, no less than a big box-office hit, running first in its number of performances in 1889-90 and 1893-94, second in 1890-91, and third in 1891-92 (Carvalho, 1993, pp. 360-363).

Now, how are we to account for this discrepancy between the interlingually and intersemiotically received Shakespeares? A weak answer would certainly look for factors such as Verdi's popularity or, what seems to me, a tendency to read Shakespeare's Othello across a generic shift, that is, under the dominant form of bourgeois melodrama instead of as a tragedy. The libretto of Rossini's Otello, for instance, was presented in 1836 as a "serious melodrama". A strong answer, though, is 
one that straightforwardly addresses the historical and ideological issues I have been dealing with here and focuses on the position of opera in the Portuguese market of symbolic goods. As I mentioned before, from its origins onwards, opera was geared towards cultural consumption by the social and political elite, in particular the court, the aristocracy and foreign diplomats, thus a mark of distinction, to employ Pierre Bourdieu's famous concept. During British occupation in the wake of the Peninsular War, the Lisbon Opera House was even deemed the only theatre offering entertainment worthy of the occupying force's tastes and status (Santos, 1983, p. 200). In this context, it is perhaps no wonder that at the time of the Ultimatum, appropriated Shakespeare should get caught up in the power struggles that set in opposition dynastic conservatives and Republican nationalists, should have been banned by anti-British sentiment while openly enjoyed by those "faithful subjects" (Teixeira, 1990 , p. 109) which were held responsible for the country's allegedly shameful capitulation in the face of the rival imperialism. Seen in this light, the itinerary of protest followed by the crowd that gathered on the streets of Lisbon as soon as the events were made public becomes highly significant. As widely reported by the press, on the night of January $12^{\text {th }}$ an angry crowd stormed the Opera House and boycotted the performance, thus symbolically enacting the overthrow of a cultural and political order that had come to embody complicity and compliance with British interests and values.

To conclude on a theoretical note, what this case study shows first and foremost is that not only translated texts are constrained by recipient agendas ideological or other; domestication may result in a highly symptomatic absence of texts, which can only be perceived and therefore investigated if we start from Gideon Toury's assertion that "concrete texts in languages other than the target's are not part of the necessary equipment for launching research." (1995, p. 34) Apparently, one does not even need a target text to do Translation Studies.

University of Lisbon 
APPENDIX 1

Translated Shakespeare in Portugal 1874-1900

\begin{tabular}{|c|c|c|c|c|c|c|c|c|c|c|c|c|c|c|c|c|c|c|c|c|c|c|c|c|c|c|c|}
\hline Translations & \multicolumn{27}{|c|}{ Publication dates } \\
\hline 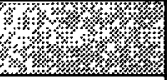 & 1874 & 1875 & 1876 & 1877 & 1878 & 1879 & 1880 & 1881 & 1882 & 1883 & 1884 & 1885 & 1886 & 1887 & 1888 & 1889 & 1890 & 1891 & 1892 & 1893 & 1894 & 1895 & 1896 & 1897 & 1898 & 1899 & 1900 \\
\hline $\begin{array}{c}\text { Midsummer } \\
\text { N. Dream }\end{array}$ & $F_{1}$ & $\mathbf{F}_{2}$ & & & & & & & & & & & & & & & & & & & & & & & . & & \\
\hline Hamlet & & & & $F_{1}$ & & $\mathbf{F}$ & $\mathrm{F}_{2}$ & FoL1 & $\begin{array}{c}\mathrm{F}_{\mathrm{OL}, 2} \\
\mathrm{~F}_{1}\end{array}$ & & $P$ & & $P$ & $\begin{array}{c}\mathrm{F} 2 \\
\mathrm{~F}\end{array}$ & & $\begin{array}{l}\mathbf{F} \\
\mathbf{P}\end{array}$ & & & & & & & & & & & $\mathbf{F}$ \\
\hline $\begin{array}{c}\text { The Merchant } \\
\text { of Venice }\end{array}$ & & & & & & $\mathbf{F}$ & & $\mathrm{F}$ & & & & & & & & & & & & & & & & & & & \\
\hline Julius Caesar & & & & & & $\mathbf{P}$ & & & & & & & & & & & & & & & & & & & & & $F$ \\
\hline Othello & & & & & & & $\mathbf{P}_{1}$ & & F & & & $\begin{array}{l}\mathbf{F} \\
\mathrm{P}_{2}\end{array}$ & & $\begin{array}{c}\mathbf{P} \\
\mathbf{F}_{\mathrm{OL}}\end{array}$ & & & & & & & & & & & & & \\
\hline Richard III & & & & & & & $F$ & & & & & & & & & & & & & & & & & & & & $\mathrm{~F}$ \\
\hline $\begin{array}{c}\text { Romeo and } \\
\text { Juliet }\end{array}$ & & & & & & & & & $\mathrm{F}_{\mathrm{Ol}}$ & & & $P$ & & $\mathrm{~F}_{\mathrm{OL}}$ & & & & & & & & & & & & & \\
\hline $\begin{array}{l}\text { Merry W. of } \\
\text { W. [Falstaff }\end{array}$ & & & & & & & & & & & & & & & & & & & & & Fol & & & & & $\mathrm{P}_{7}$ & \\
\hline $\begin{array}{l}\text { Henry IV } \\
\text { [Falstaff] }\end{array}$ & & & & & & & & & & & & & & & & & & & & & & & & & & $\begin{array}{l}\mathrm{P}- \\
\mathrm{P}\end{array}$ & \\
\hline Henry VI & & & & & & & & & & & & & & & & & & & & & & & & & & & F \\
\hline Sonnets & & & & & & & & & & & & & & & & & & & & & & $\mathbf{P}$ & & & & & \\
\hline
\end{tabular}

Notations: $F=$ full-text translation $P=$ partial translation $\quad 1=$ first edition $2=$ second edition $\quad \mathrm{o}=$ opera libretti 


\section{References}

\section{Published sources of data}

Fundo British Council [Catalogue] (1984). Lisboa, Fundação Calouste Gulbenkian.

RODRIGUES, A. A. Gonçalves (eds.) (1992-1999). A tradução em Portugal. Lisboa, Imprensa Nacional-Casa da Moeda/ICLP/ISLA, 5 vols.

2. Works cited

AFONSO, Maria João da Rocha (1990). "As versões portuguesas de King Lear". João Almeida Flor (ed.). Colóquio Shakespeare. Lisboa, Fundação Calouste Gulbenkian, pp. 65-77.

- (1993). "Simão de Melo Brandão and the First Portuguese Version of 'Othello' ". Dirk Delabastita and Lieven D'hulst (eds.). European Shakespeares: Translating Shakespeare in the Romantic Age. Amsterdam/Philadelphia, John Benjamins, pp. 129-146.

ALTHUSSER, Louis (1966). For Marx. Trans. Ben Brewster. Harmonsdworth, Penguin.

- (1970). Reading Capital. Trans. Ben Brewster. New York, Pantheon.

ANDERSON, Benedict (1991). Imagined Communities: Reflections on the Origin and Spread of Nationalism. Verso, London and New York (revised edition).

AXELSON, Eric (1967). Portugal and the Scramble for Africa. Johannesburg, Witwatersrand University Press.

BASSNETT, Susan (1993). "At the Edges of the World: Drawing New Maps". Comparative Criticism. $\mathrm{n}^{\circ} 15$, pp. 35-56.

-(1993-1994). "Taking the Cultural Turn in Translation Studies". Dedalus-Revista Portuguesa de Literatura Comparada. $\mathrm{n}^{\text {os }} 3-4$, pp. 171179. 
BRANCO, Camilo Castelo (1906). Esboço de critica. Othello, o Mouro de Veneza de William Shakespeare (tragédia traduzida para portuguez por D. Luiz de Bragança). Porto, Livraria Chardron (first edition 1886).

CARVALHO, Mário Vieira de (1993). Pensar é morrer ou o Teatro $S$. Carlos na mudança de sistemas sociocomunicativos desde os fins do séc. XVIII aos nossos dias. Lisboa, Imprensa Nacional-Casa da Moeda.

CHAMBERLAIN, Lori (1988). "Gender and the Metaphorics of Translation". Signs: Journal of Women in Culture and Society. vol. 13, $\mathrm{n}^{\circ} 3$, pp. 454-472.

CLARENCE-SMITH, Gervase (1985). The Third Portuguese Empire 1825-1975: A Study in Economic Imperialism. Manchester, Manchester University Press.

COELHO, Maria Teresa Pinto (1996). Apocalipse e regeneração: o Ultimatum e a mitologia da Pátria na literatura finissecular. Lisboa, Cosmos.

ESTORNINHO, Carlos (1964). "Shakespeare na literatura portuguesa". Ocidente. n 67, pp. 114-123.

FLOR, João Almeida (1985). "Shakespeare, Rosas \& Brazão". Miscelânea de estudos dedicados a Fernando de Mello Moser. Lisboa, Faculdade de Letras, pp. 233-246.

GROSMAN, Meta (1994). "Cross-Cultural Awareness: Focusing on Otherness". Cay Dollerup and Anette Lindegaard (eds.). Teaching Translation and Interpretation 2: Insights, Aims, Visions. Amsterdam/Philadelphia, John Benjamins, pp. 51-57.

HAMMOND, Richard J. (1966). Portugal and Africa 1815-1910: A Study in Uneconomic Imperialism. Stanford, Stanford University Press.

HOMEM, Amadeu Carvalho (1985). "Memória sobre as causas do ultimato inglês de 1890". Biblos. $n^{\circ}$ 61, pp. 453-471. 
JORGE, Maria do Céu Saraiva (1941). Shakespeare em Portugal, unpubl. diss., Lisboa, Faculdade de Letras.

LAMBERT, José (1995). "Literatures, Translation and (De)Colonization". Theresa Hyun and José Lambert (eds.). Translation and Modernization. Proceedings of the XIII ${ }^{\text {th }}$ Congress of the International Comparative Literature Association. Tokyo, vol. 4, pp. 98-117.

NOWELL, Charles E. (1982). The Rose-Colored Map: Portugal's Attempt to Build an African Empire from the Atlantic to the Indian Ocean. Lisboa, Junta de Investigação Científica do Ultramar.

PESTANA, Alice (1930). In Memoriam. Madrid, n.p.

REBELO, Luís Francisco (1978). Dicionário do Teatro Português. Lisboa, Prelo.

SANTOS, Maria de Lourdes Lima dos (1983). Por uma sociologia da cultura burguesa em Portugal no século XIX. Lisboa, Presença/Instituto de Ciências Sociais.

- (1985). Intelectuais portugueses na primeira metade de Oitocentos. Lisboa, Presença.

SENA, Jorge de (ed. and trans.) (1978). Poesia do Século XX: de Thomas Hardy a C. V. Cattaneo. Porto, Inova.

SEQUEIRA, Gustavo Matos (1955). História do Teatro Nacional D. Maria II. Lisboa (Publicação Comemorativa do Centenário 1846-1946), 2 vols., vol. 1.

SIMON, Sherry (1996). Gender in Translation: Cultural Identity and the Politics of Transmission. London and New York, Routledge.

TEIXEIRA, Nuno Severiano (1990). O Ultimatum inglês: politica externa e política interna. Lisboa, Alfa.

TELES, Basílio (1968). Do Ultimatum ao 31 de Janeiro: esboço de história política. Lisboa, Portugália (first edition 1905). 
TELO, António José (1991). Lourenço Marques na política externa portuguesa 1875-1900. Lisboa, Cosmos.

TOURY, Gideon (1982). "A Rationale for Descriptive Translation Studies". Dispositio. vol. 7, nos 19-20, pp. 23-39.

- (1995). Descriptive Translation Studies and Beyond, Amsterdam/Philadelphia, John Benjamins.

\begin{abstract}
The Politics of Non-Translation: A Case Study in Anglo-Portuguese Relations - One of the most fruitful paths opened up by the functionalist, target-oriented, turn in the study of the translation has been the possibility of taking into theoretical and analytical account objects that are epistemologically identifiable as being empirically absent. Non-translation, both at a lexical or a textual level, becomes thus available for research. In this context, the present paper has a double purpose: to describe a set of non-translation categories and to discuss a case of ideologically driven absence of translation. This case study concerns an intriguing episode in Shakespeare reception in Portugal: the almost complete lack of new translations from Shakespeare's works into the last decade of the nineteenth century following a fifteen-year period of intense translational activity and unprecedented popularity enjoyed by Shakespeare in the target culture. It was found that such a striking instance of non-translation was due to a nation-wide wave of anti-British nationalism that swept the country in the wake of colonial rivalry over a portion of territory in Southern Africa.
\end{abstract}

RÉSUMÉ : Une politique de non-traduction dans le cadre des relations anglo-portugaises - La possibilité de considérer les aspects théoriques et analytiques d'objets catégorisés, d'un point de vue épistémologique, empiriquement absents a été l'une des avenues les plus prometteuses découlant de la nouvelle orientation fonctionnaliste et cibliste de la traductologie. La non-traduction devient donc accessible à la recherche au niveau tant lexical que textuel. Dans ce contexte, le présent article vise deux objectifs: établir des catégories de non-traduction et examiner une situation où l'on évite délibérément de traduire pour des raisons idéologiques. Cette étude de cas porte sur l'histoire de l'accueil fait aux cuvres de Shakespeare au Portugal alors qu'une période de quinze années intenses de traduction et de popularité 
sans précédent a fait place à l'absence quasi totale de nouvelles traductions en portugais durant la dernière décennie du XIX ${ }^{\mathrm{e}}$ siècle. On remarque que ce cas probant de non-traduction découlait d'une vague nationaliste anti-britannique qui a balayé le pays à la suite du conflit colonial portant sur une partie des territoires de l'Afrique du Sud.

Key words: target-orientedness, non-translation, Shakespeare translation, nationalism, history of translation in Portugal.

Mots-clés : orientation cibliste, non-traduction, traduction de Shakespeare, nationalisme, histoire de la traduction au Portugal.

João Ferreira Duarte : Faculdade de Letras, Universidade de Lisboa, Alameda da Universidade, 1600-214 Lisboa

E-Mail : joduarte@mail.telepac.pt 